\title{
Cutaneous myxoma in a pintagol (Sporagra magellanica X Serinus canaria)
}

\author{
Mixoma cutâneo em um pintagol
}

\begin{abstract}
Guilherme Reis Blume ${ }^{\mathrm{I}}$ Fernanda Mara Aragão Macedo Pereira ${ }^{\mathrm{II}}$ Janildo Ludolf Reis Júnior ${ }^{I}$ Fabiano José Ferreira de Sant'Ana ${ }^{{ }^{*}}$
\end{abstract}

\section{- NOTE -}

\section{ABSTRACT}

Myxomas are benign mesenchymal tumors rarely described in birds. This report describes the clinical and pathological findings in a case of myxoma in a pintagol (Sporagra magellanica $X$ Serinus canaria). The animal had a nodule on the dorsal region of the third digit on the left hindlimb. Grossly, it was a $0.9 \times 0.5 \times 0.4 \mathrm{~cm}$, soft, white nodule, with black and yellow areas on the cut surface. Microscopically, a well-differentiated monomorphic population of spindle cells arranged in an abundant Alcian blue-positive myxoid matrix was observed. The diagnosis of myxoma was based on the microscopic findings.

Key words: dermatopathology, neoplasm, oncology.

RESUMO

Mixomas são tumores mesenquimais benignos incomuns em aves. Este trabalho objetiva descrever os achados clínico-patológicos de um caso de mixoma em um pintagol. A ave apresentou aumento de volume na região dorsal do terceiro dígito do membro pélvico esquerdo. Macroscopicamente, notouse um nódulo de 0,9x0,5x0,4cm, macio, esbranquiçado, com áreas amareladas e enegrecidas na superficie de corte. A histopatologia revelou população monomórfica de células fusiformes, com baixo pleomorfismo, arranjadas em meio à matriz mixóide positiva para a coloração de azul alciano. Com base nos achados histopatológicos, foi firmado o diagnóstico de mixoma.

Palavras-chave: dermatopatologia, neoplasia, oncologia.

Myxoma is a benign neoplasm of mesenchymal cells producing a myxomatous matrix. This tumor is diagnosed occasionally in adult dogs and cats and rarely in birds (YANG \& LEE, 1987; REECE, 1992) or other species (GOLDSCHIMIDT \&
HENDRICK, 2002). There are sporadic descriptions of this neoplasm in some species of domestic birds, such as Gallus gallus (YAMAN et al., 2004), but there is no report of this tumor in pintagols. This bird, usually kept in domestic places, is the result of crossing the hooded siskin (Sporagra magellanica) with the canary (Serinus canaria).

In birds, myxoma can arise from any structure that contains connective tissue, including the cranium, hindlimbs, kidneys, commissure of the beak, and the celomatic cavity (REECE, 1992). In other species, it frequently affects the heart, bones, skin, subcutaneous tissue, aponeurosis, reproductive and urinary tracts, and skeletal muscle (ALLEN, 2000). When there is suspicion of swelling in these tissues, histopathologic analysis is essential to diagnose the tumor and differentiate it from other mesenchymal neoplasms and inflammatory or degenerative processes (GOLDSCHIMIDT \& HENDRICK, 2002). On clinical examination, soft masses with gelatinous cut surface are observed on palpation (LATIMER, 1994). This report describes the clinical and pathological findings of a rare case of cutaneous myxoma in a pintagol. This appears to be the first description of this neoplasm in this species of bird.

A 3-year-old male pintagol presented with a history of swelling in the dorsal region of the third digit of the left hindlimb. On clinical examination, a $0.9 \times 0.5 \times 0.4 \mathrm{~cm}$, soft, white nodule with yellow and black areas was identified. The bird did not seem to show any discomfort because of the lesion and did not present any behavioral changes.

\footnotetext{
'Laboratório de Patologia Veterinária, Universidade de Brasília (UnB), 70910-900, Brasília, DF, Brasil. E-mail: santanafjf@yahoo.com. ${ }^{*}$ Corresponding author.

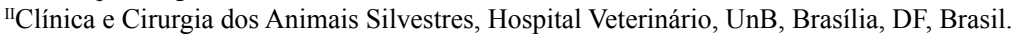


After clinical examination, surgical excision of the nodule was performed, and the sample was submitted for histopathology. Sedation and analgesia were performed using butorphanol tartrate (4mg kg-1 ${ }^{-1}$ Torbugesic ${ }^{\circledR}$, Zoetis, Campinas/SP, Brazil). Gross examination of the nodule revealed a soft, white tissue with a regular cut surface. The sample was fixed in buffered $10 \%$ formalin, routinely processed, and stained with hematoxylin and eosin (HE) and Alcian blue $\mathrm{pH}$ 2.5. After excision of the nodule, a dressing was placed on the site, and the bird received an intramuscular injection of meloxicam $(0.2 \mathrm{mg}$ $\mathrm{kg}^{-1}$, Maxicam ${ }^{\circledR}$, Ouro Fino, Cravinhos/SP, Brazil).

Microscopically, the superficial and deep dermis were found to be expanded and replaced by a nonencapsulated, moderately cellular, poorly demarcated, nodular, neoplastic proliferation. The adjacent epidermis was compressed by the neoplasm (Figure 1A). The lesion was composed of loosely arranged bundles of cells in an abundant myxoid matrix (Figure 1B). The neoplastic cells were spindle or stellate with poorly demarcated borders and eosinophilic and had scarce cytoplasm. The nuclei were oval and paracentral, single or double, with loose chromatin and single or double prominent nucleoli. Mild anisocytosis and anisokaryosis were present, along with rare mitotic figures. Additionally, some heterophils, lymphocytes, and plasma cells were observed together with the neoplastic proliferation. The myxoid matrix presented strong positive labeling to mucin on Alcian blue pH 2.5 staining (Figure 1C).

The bird recovered normally from anesthesia and showed clinical improvement postoperatively. Recurrence was not observed within 11 months postoperatively. Based on the clinical, gross, and mainly histopathologic findings, the bird was diagnosed with myxoma. This appears to be the first report of this neoplasm in this species of bird.

Neoplasms of connective tissue originate from poorly differentiated fibroblasts and can produce collagenous (fibroma/fibrosarcoma) or mucinous (myxoma/myxosarcoma) stroma. In some cases, it is difficult to classify and distinguish between benign and malignant neoplasms, for which assessment of

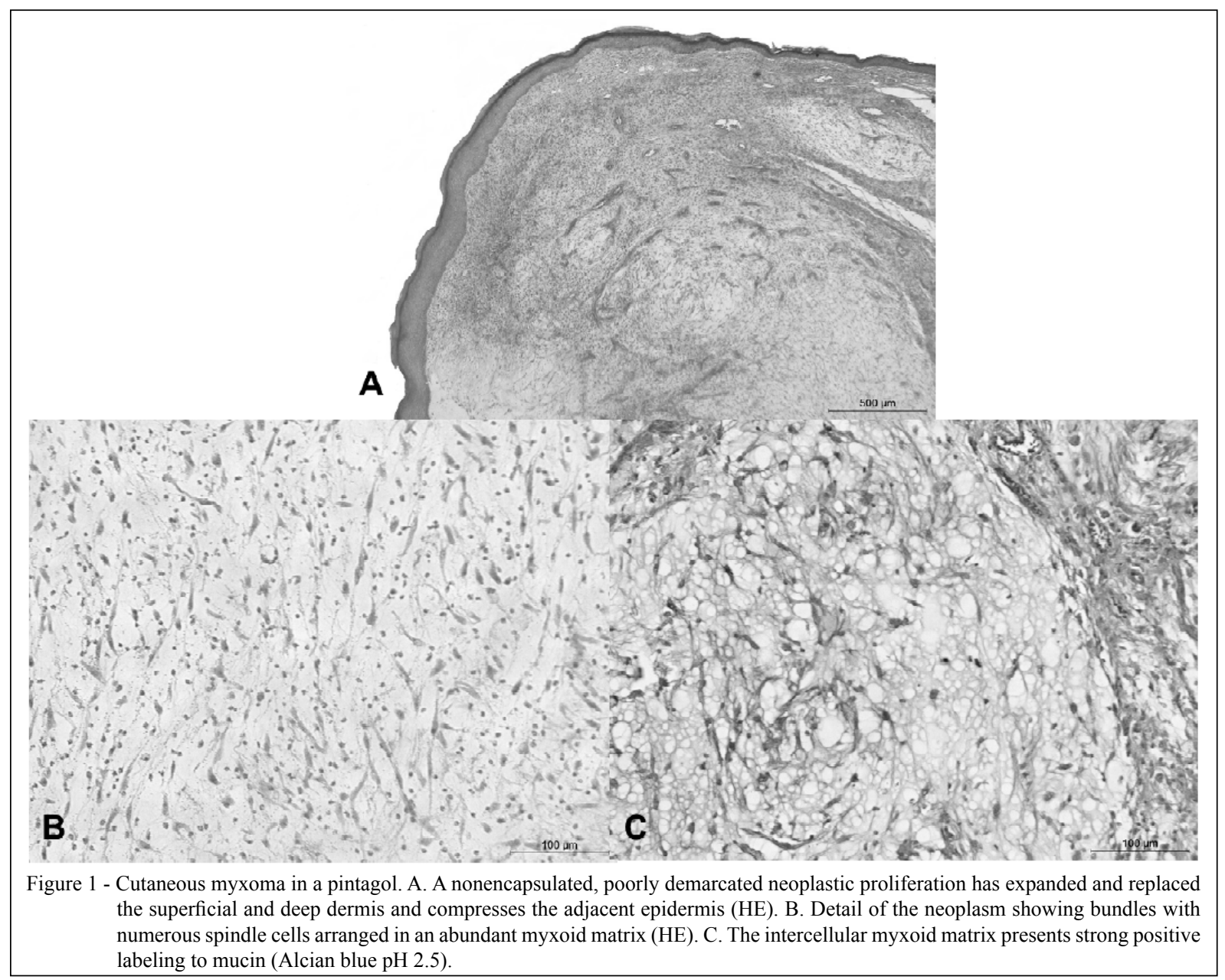

Ciência Rural, v.45, n.9, set, 2015. 
cell morphology, mitotic index, and biologic behavior is required (LATIMER, 1994; GOLDSCHIMIDT \& HENDRICK, 2002). In a study evaluating 1333 neoplasms in passerines over a 6-year period, 16 cases were detected in pintagols (SINHORINI, 2008). In that study, there were no cases of myxoma or myxosarcoma, and only two neoplasms were diagnosed in pintagols: cloacal papilloma and subcutaneous liposarcoma.

The myxoma-related pathologic findings observed in the case reported here are similar to those reported in other birds, which are described as occurring in the spleen, crop, skin, kidney, and thoracic cavity (WEST, 1974; REECE, 1992; YAMAN et al., 2004). Apparently, as seen in the present case, myxoma and myxosarcoma have low metastatic potential in birds (LATIMER, 1994). Because myxoma is an infiltrative neoplasm, postoperative recurrences can occur (GOLDSCHIMIDT \& HENDRICK, 2002), but this was not observed in the present case. The main differential diagnosis for myxoma is fibroma; the presence of mucin (Alcian blue $\mathrm{pH} 2.5$-positive) in the intercellular matrix confirms the diagnosis of myxoma (YAMAN et al., 2004), as seen in the present case.

\section{REFERENCES}

ALLEN, P.W. Myxoma is not a single entity: a review of the concept of myxoma. Annals of Diagnostic Pathology, v.4, n.2, p.99-123, 2000. Available from: <http://www.annalspathology. com/article/S1092-9134(00)90019-4/abstract>. Accessed: Nov. 17, 2014. doi: 10.1053/adpa.2000.0099.
GOLDSCHIMIDT, M.H.; HENDRICK, M.J. Tumors of the skin and soft tissues. In: MEUTEN, D.J. Tumors in domestic animals. 4.ed. Ames, IA: Iowa State University, 2002. Cap.2, p.45-117.

LATIMER, T.L. Oncology. In: RITCHIE, B.W. et al. Avian medicine: principles and application. Lake Worth: Wingers Publishing, 1994. Cap. 25, p.640-672.

PAYNE, L.N. Retrovirus-induced disease in poultry. Poultry Science, v.77, n.8, p.1204-1212, 1998. Available from: <http:// ps.oxfordjournals.org/content/77/8/1204>. Accessed: Oct. 24, 2014. doi:10.1093/ps/77.8.1204.

REECE, R.L. Observations on naturally occurring neoplasms in birds in the state of Victoria, Australia. Avian Pathology, v.21, n.1, p.3-32, 1992. Available from: <http://dx.doi.org/10.1080/030 79459208418815>. Accessed: Oct. 26, 2014. doi: 10.1080/03079 403079459208418815.

SINHORINI, J.A. Neoplasias em aves domésticas e silvestres mantidas em domicílio: avaliação anatomopatológica e imunoistoquímica. 2008. 131f. Dissertação (Mestrado em Patologia Experimental e Comparada) - Curso de Pós-graduação em Medicina Veterinária, Universidade de São Paulo, SP.

YAMAN, I. et al. Case report of a myxoma in a gamecock. Veterinary Medicine - Czech, v.49, n.7, p.268-270, 2004. Available from: <http://vri.cz/docs/vetmed/49-7-268.pdf $>$. Accessed: Nov. 1, 2014.

YANG, S.Y.; LEE, S.H. Neoplasms identified in chickens and pigeons in Taiwan. Journal of the Chinese Society of Veterinary Science, v.13, p.81-88, 1987.

WEST, J.L. An avian splenic myxoma. Avian Diseases, v.18, n.1, p.139-141, 1974. Available from: <http://www.jstor.org/ stable/1589253>. Accessed: Oct. 26, 2014. 